\title{
The Impact of Daily Prayers Multimedia Application towards Student's Learning Interest
}

\author{
Eka Prasetya Adhy Sugara ${ }^{1}$, Guntoro Barovih ${ }^{2}$, Nurussama $^{3}$ \\ \{ $\underline{\text { eka_p@palcomtech.ac.id }}$, guntoro@palcomtech.ac.id ${ }^{2}$, nurussama@palcomtech.ac.id ${ }^{3}$ \} \\ 1,3Politeknik PalComTech, Jl. Basuki Rahmat No. 05 Palembang, 30129 Indonesia \\ ${ }^{2}$ STMIK PalComTech, Jl. Basuki Rahmat No. 05 Palembang, 30129 Indonesia
}

\begin{abstract}
Multimedia is one method that can help improve the learning process. Several previous studies which stated that multimedia can help increase children's interest and learning motivation. Some other studies even state the application of multimedia in the learning process can improve student understanding and value in learning. However, not a few studies that state otherwise. Some research states that the application of multimedia in the learning process can disrupt student concentration. This study aims to determine whether there is an impact in using daily prayer learning applications on children's learning interests. The object of research is students who study at the Darul Quddus AlQur'an Education Park. The research method used was descriptive statistical analysis. Based on the results of testing with a simple linear regression analysis, it can be concluded that the use of daily prayer learning applications has a positive impact on the learning interest of students at Darul Quddus TPA.
\end{abstract}

Keywords: Multimedia, Daily Prayers, Student Learning, Learning Interest, Analysis Statistic Descriptive.

\section{Introduction}

Childhood is a golden period for children's growth and development in all aspects. Aspects that continue to grow and develop include physical, motor, language, emotional and cognitive abilities. The childhood is a highy eventful and unique period of life of the child's growth in this phase which is very vital to the next life [1]. This period is also a golden period for the development of a child's brain. There are studies that state that children's intelligence capacity has reached $50 \%$ at 4 years of age and will increase to $80 \%$ at 8 years of age [2]. This shows the importance of providing the right stimulus as an educational medium for children. One stimulus that can be used as an educational medium is through the use of multimedia.

The application of multimedia as an educational tool for children is not a new matter. Much research has been done to develop multimedia-based applications as media aids in the learning process. Some applications are developed, for example in the form of educational games to learn shapes and colors of objects [3], multimedia applications for learning to read, write and count (calistung) [4], multimedia learning to recognize letters and numbers [5], games to stimulate cognitive aspects and child language [6], profession recognition application [7] and speech and animal object recognition application [8]. According to Yamin in [9] there are no less than five multimedia benefits in learning, namely the delivery of subject matter can be uniformed, the learning process becomes more interesting, the learning process becomes more interactive, the amount of teaching and learning time can be reduced and the quality of student learning can be improved. It remains to be understood that the use of 
multimedia cannot replace conventional learning, but can improve and have an impact on activities outside and inside the classroom [10].

The many uses of multimedia as a learning aid media also have an impact on student learning interests. Slameto in [11] defines interest as a sense of love and interest that is so great towards something without coercion from anyone. Interest in learning has four main indicators, i.e. feelings of pleasure, interest, attention and student involvement. Many previous studies have stated the positive effects of using multimedia as an educational medium on student interest in learning. References [12] states there is a positive influence on the use of instructional media on elementary school students in Islamic Religious Education subjects. References [13] states that there is a positive influence on the use of animated interactive media on interest in learning mathematics in elementary school students. However, reference [14] states the negative effects of the use of multimedia elements on students aged 3-6 years. This means that the use of multimedia as a means of education does not always have a positive impact.

This study aims to determine the impact of the use of animation-based daily prayer learning applications for the learning interests of Darul Quddus Al-Qur'an Education (TPA) students. The application was developed as a media to help daily prayer learning as an alternative to conventional learning. Utilization of the application is one of several forms of Community Partnership Program (PKM) activities carried out by [15]. The partners involved in the PKM activities are teaching staff or Ustadzah and TPA Darul Quddus students. The research method uses descriptive statistical analysis to determine whether there is an influence between the use of learning applications with student learning interests. The hypothesis proposed is there is a positive effect on the use of daily prayer learning applications to the learning interest of students at TPA Darul Quddus.

\section{Methods}

The method used in this study consisted of several stages. The first stage begins by determining the type of research. This research belongs to the type of quantitative research, which examines how much influence the independent variable has on the dependent variable. This research method is used in certain populations or samples taken randomly, collecting data using research instruments and analyzing quantitative or statistical data to test the hypotheses that have been established [16]. The approach used is an approach with simple linear regression analysis, which analyzes the linear relationship between one independent variable with one dependent variable. The independent variable measured in this study was the use of multimedia-based daily prayer learning media, while the dependent variable was the learning interest of TPA Darul Quddus children. The study population was students who study at TPA Darul Quddus.

The next stage is gathering data. The data collection technique used was a questionnaire. Questionnaire is a data collection technique that is done by giving a set of questions or written statements to respondents to be answered. Questionnaires are efficient data collection techniques when researchers know the variables to be measured and know what respondents can expect. Questionnaires can be closed or open questions or statements, can be given to respondents directly or sent by post, or the internet [16]. The use of questionnaires in data collection has several advantages including practical, economic and people can answer openly and freely [17]. This study uses a closed questionnaire where the questions provided by researchers use predetermined answers with a check selection model with varying value criteria. The statements used consist of positive and negative statements. For positive statements, the "always" answer is 4, the "often" answer is 3 , the "sometimes" answer is 2 and 
the "never" answer is 1 . While for negative statements, the evaluation of the answer is the opposite. The questionnaire consisted of 10 questions for both independent variable and the dependent variable. It were filled out by 50 children who were studying at the Darul Quddus TPA with the assistance of the ustadzah.

The last step is data analysis. Patton in [18] states that data analysis is the process of arranging data sequences, organizing them into patterns, categories and basic units of description. Through the process of analysis, data can be given meaning and meaning that is useful in solving research problems, research data analysis aims to simplify and limit the findings to become one organized data, arranged and more meaningful. The steps taken to analyze the data of this research are by conducting instrument testing and analysis prerequisite testing. Instrument testing consists of validity and reliability tests, while analysis prerequisite testing is done by testing data normality and hypothesis testing.

\subsection{Instrument Testing}

a. Validity Test. Validity is the accuracy of an instrument in measuring what it wants to measure [19]. The validity test in this study uses Bivariate Pearson correlation. Itemtotal correlation coefficients can be searched using equation 1 :

$$
\begin{aligned}
& \qquad r_{i x}=\frac{n \Sigma_{i x}-\left(\Sigma_{i}\right)\left(\Sigma_{x}\right)}{\sqrt{\left[n \sum i^{2}-\left(\sum i\right)^{2}\right]\left[n \sum x^{2}-\left(\sum \mathrm{x}\right)^{2}\right]}} \\
& \text { Information: } \\
& \begin{array}{ll}
r_{i x} \quad=\text { item-total coefficient (Bivariate Pearson) } \\
i & =\text { item score } \\
x & =\text { total score } \\
n & =\text { number of data }
\end{array}
\end{aligned}
$$

Items from daily use of learning media and students' learning interest are tested and the results are then compared to $r_{\text {table }}$ at a significance level of $5 \%$ or 0.05 . With the amount of data $(n)=50$, the $r_{\text {table }}$ amount is 0.279 (table $r$ product moment)

b. Reliability Test. Reliability refers to a consistency of results if the measurement is repeated twice by the same person or different people [20]. Reliability Test uses the Cronbach Alpha value. The instrument in this study was declared reliable if the alpha value was greater than $0.60(\alpha>0.60)$ and vice versa, if the alpha value was less than $0.60(\alpha<0.60)$ then the research instrument was declared unreliable.

\subsection{Prerequisite Analysis Test}

a. Normality Test. Normality test is used to determine whether the population data is normally distributed or not [21]. This test is usually used to measure data on ordinal scale, intervals, or ratios. If the analysis uses parametric methods, then the requirements must be fulfilled, i.e. the data comes from a normal distribution. If the data are not normally distributed, or the number of samples is small and the type of data is nominal or ordinal, the method used is nonparametric statistics [19]. This study uses the Komlogorov-Smirnov test to detect whether data normality is normally distributed or not. If probability or Asymp. Sig. (2-tailed) is greater than the level of significant $(\alpha)$, then the data is normally distributed.

b. Hypothesis Test. Hypothesis test in this study consisted of a simple linear regression test and t test. Simple linear regression analysis is used to analyze the linear relationship between one independent variable with one dependent variable [22]. 
This analysis allows researchers to determine the direction of the relationship between the independent variable with the dependent variable and to predict the value of the dependent variable if the value of the independent variable has increased or decreased. The regression equation for simple linear regression is shown by equation 2 :

$$
\begin{aligned}
& \text { Information: } \\
& \begin{array}{ll}
Y^{\prime} & =\text { Dependent Variable } \\
\mathrm{X} & =\text { Independent Variable } \\
\mathrm{a} & =\text { Constant } \\
\mathrm{b} & =\text { Regresssion Coefficient }
\end{array}
\end{aligned}
$$$$
Y^{\prime}=a+b X
$$

$\mathrm{T}$ test is done to show whether there is an influence of one independent variable as an individual on the related variable. The $\mathrm{T}$ test is used to test the significance of the relationship between the variables $\mathrm{X}$ and $\mathrm{Y}$, whether the independent variables really affect the dependent variable separately or partially. To interpret the coefficient of the independent variable (independent) can use the unstandardized coefficient and standardized coefficient by looking at the significance value of each variable at the significance level $\alpha=5 \%$ (0.05). If the significant value of $\mathrm{t}_{\text {count }}<\mathrm{tt}_{\mathrm{able}}$ and $\alpha>0.05$ then there is no significant effect of the independent variable on the dependent variable. If significant $t_{\text {count }}>t_{\text {table }}$ and $\alpha<0.05$ then there is a significant influence between the independent variables on the dependent variable.

\section{Result and Discussion}

Based on the results of data processing the independent variable use of daily learning media based on animation (x) and the free variable children's learning interest (y) towards 50 respondents, the following results are obtained:

\subsection{Instrument Testing Result}

a. Validity Test Result. The results of correlation testing with Bivariate Pearson on 10 instrument items from the use of daily learning multimedia application are shown in Table 1. The results of correlation testing with 10 items of student's learning interest are shown in Table 2.

Tabel 1. Multimedia Application Correlation Test Result

\begin{tabular}{llll}
\hline $\mathrm{N}$ of Item & $\mathrm{R}_{\text {count }}$ & $\mathrm{r}_{\text {table }}$ & Result \\
\hline $\mathrm{X} 1.1$ & 0.423 & 0.279 & Valid \\
$\mathrm{X} 1.2$ & 0.404 & 0.279 & Valid \\
$\mathrm{X} 1.3$ & 0.667 & 0.279 & Valid \\
$\mathrm{X} 1.4$ & 0.371 & 0.279 & Valid \\
$\mathrm{X} 1.5$ & 0.413 & 0.279 & Valid \\
$\mathrm{X} 1.6$ & 0.627 & 0.279 & Valid \\
$\mathrm{X} 1.7$ & 0.783 & 0.279 & Valid \\
$\mathrm{X} 1.8$ & 0.705 & 0.279 & Valid \\
$\mathrm{X} 1.9$ & 0.610 & 0.279 & Valid \\
$\mathrm{X} 1.10$ & 0.681 & 0.279 & Valid \\
\hline
\end{tabular}


Tabel 2. Student's Learning Interest Correlation Test Result

\begin{tabular}{cccc}
\hline $\begin{array}{c}\mathrm{N} \text { of } \\
\text { Item }\end{array}$ & $\mathrm{R}_{\text {count }}$ & $\mathrm{R}_{\text {table }}$ & Result \\
\hline $\mathrm{X} 1.1$ & 0.550 & 0.279 & Valid \\
$\mathrm{X} 1.2$ & 0.461 & 0.279 & Valid \\
$\mathrm{X} 1.3$ & 0.453 & 0.279 & Valid \\
$\mathrm{X} 1.4$ & 0.740 & 0.279 & Valid \\
$\mathrm{X} 1.5$ & 0.491 & 0.279 & Valid \\
$\mathrm{X} 1.6$ & 0.630 & 0.279 & Valid \\
$\mathrm{X} 1.7$ & 0.431 & 0.279 & Valid \\
$\mathrm{X} 1.8$ & 0.527 & 0.279 & Valid \\
$\mathrm{X} 1.9$ & 0.345 & 0.279 & Valid \\
$\mathrm{X} 1.10$ & 0.388 & 0.279 & Valid \\
\hline
\end{tabular}

The test results shown in Table 1 and Table 2 show that all items on the instructional media instrument and learning interest, both of them show a $r_{\text {count }}$ value higher than the $r_{\text {table }}$ value. Based on this, it can be concluded that the instrument used is valid.

b. Reliability Test Result. The results of reliability testing using the Cronbach Alpha value of 10 items of learning media are shown in Table 3, while the results of the reliability test for 10 items of children's learning interest are shown in Table 4.

Tabel 3. Multimedia Application Reliability Test Result

\begin{tabular}{cl}
\hline \multicolumn{2}{c}{ Cronbach's } \\
Alpha & N of Items \\
\hline .766 & 10 \\
\hline
\end{tabular}

Tabel 4. Student's Learning Interest Reliability Test Result

\begin{tabular}{cl}
\hline \multicolumn{2}{c}{ Cronbach's } \\
Alpha & N of Items \\
\hline .669 & 10 \\
\hline
\end{tabular}

The results of the reliability testing of the instructional media instrument and learning interest, both showed Alpha Cronbach values greater than 0.6. Based on the measure of alpha stability with a range of values of $0.61-0.80$ [23], it can be concluded that the instrument used is reliable.

\subsection{Hypothesis Test Result}

a. Normality Test Result. The results of data normality testing using the KolmogorovSmirnov one-sample method are shown in Table 5. 
Tabel 5. 1-S Kolmogorov-Smirnov Normality Test Result

\begin{tabular}{llcl}
\hline & & $\begin{array}{c}\text { Daily Prayers } \\
\text { Application }\end{array}$ & $\begin{array}{l}\text { Students } \\
\text { Learning Interest }\end{array}$ \\
\hline $\mathrm{N}$ & Mean & 39.6000 & 30 \\
Normal & Mea.6000 & 38.600 \\
Parameters $^{\mathrm{a}, \mathrm{b}}$ & Std. & 3.77964 & 3.30121 \\
& Deviation & & .108 \\
Most & Absolute & .104 & .082 \\
Extreme & Positive & .104 & -.108 \\
Differences & Negative & -.072 & .108 \\
Test Statistic & & .104 & $.199^{\mathrm{c}}$ \\
Asymp. Sig. (2-tailed) & $.200^{\mathrm{c}, \mathrm{d}}$ & \\
\hline
\end{tabular}

The results of the One-Sample Kolmogorov-Smirnov test show that learning applications and children's interest in learning both have Asymp. Sig. values is greater than 0.05 . Learning media has a value of .200 while interest in learning has a value of .199. These results indicate that the data used in this study are normally distributed.

b. Hypothesis Test Result. The results of the simple linear regression analysis are shown in Table 6 and Table 7. Table 6 shows the results of the model summary while Table 7 shows the coefficient values of the simple linear regression analysis.

Tabel 6. Model Summary

\begin{tabular}{|c|c|c|c|}
\hline Model & $\begin{array}{l}\text { R } \\
\text { R Square }\end{array}$ & $\begin{array}{l}\text { Adjusted R } \\
\text { Square }\end{array}$ & $\begin{array}{l}\text { Std. Error of } \\
\text { the Estimate }\end{array}$ \\
\hline \multirow[t]{2}{*}{1} & $\begin{array}{ll}.4 & .21\end{array}$ & 106 & $2 \mathrm{c}$ \\
\hline & 3 & .190 & 2.9. \\
\hline
\end{tabular}

a. Dependent Variable: Student's Learning Interest

Tabel 7. Coefficients

\begin{tabular}{|c|c|c|c|c|c|}
\hline \multirow[b]{2}{*}{ Model } & \multicolumn{2}{|c|}{$\begin{array}{l}\text { Unstandardized } \\
\text { Coefficients }\end{array}$} & \multicolumn{2}{|c|}{$\begin{array}{l}\text { Standardized } \\
\text { Coefficients }\end{array}$} & \multirow[b]{2}{*}{ Sig. } \\
\hline & B & Std. Error & Beta & $\mathrm{t}$ & \\
\hline (Constant) & 22.647 & 4.449 & & 5.090 & .000 \\
\hline $\begin{array}{l}\text { Daily Prayer's } \\
\text { Application }\end{array}$ & .403 & .112 & .461 & 3.602 & .001 \\
\hline
\end{tabular}

a. Dependent Variable: Student's Learning Interest

Table 6 shows how much influence the use of learning applications variables on student learning interest variables. In the R Square column of the table, a value of 0.213 or $21.3 \%$ is obtained. These results indicate that the learning application variable affects student learning interest by $21.3 \%$, while the remaining $78.7 \%$ is influenced by other factors. Further research is needed to be able to find out other factors that can influence children's interest in learning. 
Based on the results of the multiple linear regression test in Table 7 , it can be obtained the results of the equation $\mathrm{Y}=22,647+0,403 \mathrm{X}$. The regression coefficient of the variable use of learning applications (X) of 0.403 shows that if the use of learning applications has increased 1 point, then the students' interest in learning (Y) will increase by 0.403 point. Positive coefficient means that there is a positive relationship between the use of learning with students 'learning interest, the higher the use of learning applications, the more students' interest in learning increases. Table 7 also shows the values of the t test. T test is used to find out how significant the effect of the use of learning applications on student interest in learning is partial. Based on Table 7, the value of $t$ is 3.602 which is greater than the value of t table of 1.677 and the value of sig. amounted to 0.001 which is much smaller than the value of sig. 0.05. These results indicate there is a significant influence between the use of learning applications with student learning interests.

\section{Conclusion}

Based on the results that have been described, it can be concluded that the use of daily prayer learning applications has an influence on the learning interests of students of Darul Quddus TPA students. The effect of learning applications on student learning interest is partially at $21.3 \%$, of which another $78.7 \%$ is influenced by other factors. Based on the t test, the value of $\mathrm{t}$ is 3,602 with sig. 0.001 , so the resulting effect is significant. However, this study cannot determine differences in student learning interests before and after using the application. Further research is still needed to find out whether there is an increase in student interest in learning before and after using the learning application.

Acknowledgments. The author's would like to express their deepest gratitude to the Directorate of Research and Community Service, the Directorate General of Research Strengthening and Development, the Ministry of Research, Technology and Higher Education (Kemenristekdikti) for funding this research through the PKM grant scheme at the TPA in Palembang City, which this research is one of the outcomes of the PKM at TPA Darul Quddus as mentioned.

\section{References}

[1] Santrock, W.J., Life Span Development- Perkembangan Masa Hidup, Jakarta: Erlangga, 2002.

[2] Hayati, Miratul. "Designing of Educational Game Tools for Early Childhood Development Based on Islamic Values." International Conference on Education in Muslim Society (ICEMS 2017). Atlantis Press, 2017.

[3] Dyta, Septian Eka. "Rancang bangun aplikasi game edukasi anak Untuk mengenal bentuk dan warna benda." Skripsi, Program Studi Teknik Informatika-S1 Universitas Dian Nuswantoro, Semarang, 2013.

[4] Faroqi, Adam, and Barikly Maula. "Aplikasi Multimedia Interaktif Pembelajaran Membaca, menulis, berhitung (calistung)." JURNAL ISTEK 8.2, 2014.

[5] Putra, Lovandri Dwanda, and Ishartiwi Ishartiwi. "Pengembangan multimedia pembelajaran interaktif mengenal angka dan huruf untuk anak usia dini." Jurnal Inovasi Teknologi Pendidikan 2.2, 2015, pp. 169-178. 
[6] Widyatmojo, Galih, and Ali Muhtadi. "Pengembangan multimedia pembelajaran interaktif berbentuk game untuk menstimulasi aspek kognitif dan bahasa." Jurnal Inovasi Teknologi Pendidikan 4.1, 2017, pp. 38-49.

[7] Sugara, Eka Prasetya Adhy, Mahmudi, Muhammad Ali, and Wahyudi, Sugeng, "Aplikasi Pengenalan Profesi Pekerjaan Bagi Anak Usia Dini Berbasis Augmented Reality." Riau Journal Of Computer Science 3.2, 2017, pp. 89-96.

[8] Alexander Simbolon, Fransisco, et al. "Pembuatan Aplikasi Pengenalan Suara Dan Objek Hewan Sebagai Media Pengenalan Bagi Anak Usia Dini Dengan Metode Computer Based Instruction (CBI)." Journal Of Informatic Pelita Nusantara 3.1, 2018.

[9] Rizki, Latifa Arina, "Pengaruh Penggunaan Multimedia Interaktif Berbasis Macromedia Flash Terhadap Hasil Belajar Siswa Pada Mata Pelajaran Kompetensi Dasar Kejuruan Kelas X Program Keahlian Teknik Gambar Bangunan Smk N 2 Depok", Skripsi, Program Studi Pendidikan Teknik Sipil Dan Perencanaan, Fakultas Teknik, Universitas Negeri Yogyakarta, 2014.

[10] Almara'beh, Hilal, Ehab F. Amer, and Amjad Sulieman. "The effectiveness of multimedia learning tools in education." International Journal 5.12, 2015.

[11] Akhyar, Muhammad, "Pengaruh Penggunaan Media Pembelajaran Berbasis Media Presentasi Terhadap Minat Dan Hasil Belajar Matematika Siswa Kelas X Mia Sman 1 Soppeng” Skripsi, Fakultas Tarbiyah dan Keguruan Jurusan Pendidikan Matematika, UIN Alauddin, Makassar, 2018.

[12] Amriani, "Pengaruh Penggunaan Media Pembelajaran Terhadap Minat Belajar Siswa Pada Mata Pelajaran PAI Siswa SD Inp Lasepang Kecamatan Bantaeng Kabupaten Bantaeng”, Skripsi, Fakultas Tarbiyah Dan Keguruan UIN Alauddin, Makassar, 2014.

[13] Maharani, Annisa, Riswanti Rini, and Sugiman, Sugiman. "Pengaruh Penggunaan Media Interaktif Animasi Terhadap Minat Belajar Matematika Peserta Didik." Jurnal Pedagogi 8.7, 2018.

[14] Shilpa, S. dan Sunita, M. "Negative Impact of Multimedia Elements in Early Year (36) Students' Education”, Arts and Social Sciences Journal 7.1, 2016.

[15] Barovih, G., Sugara, E.P.A. dan Nurussama. "PKM Taman Pendidikan Al-Qur'an di Kota Palembang”, Laporan Kemajuan Program Kemitraan Masyarakat (PKM). Preprints, Accessed on September, 15th 2019 from https://osf.io/preprints/inarxiv/hpc43/

[16] Sugiyono. Metode Penelitian Pendidikan, Pendekatan Kuantitatif, Kualitatif dan R\&D, Bandung: Alfabeta. 2015, pp. 14

[17] Sahara, Adinta Yasinta. "Pengaruh Pengunaan Media Audiovisual terhadap Minat Belajar Siswa Pada Mata Pembelajaran PAI Kelas X Di Sman 1 Campurdarat Tulungagung.", 2017.

[18] Tanzeh, Ahmad. Metode Penelitian Praktis, Yogyakarta: Teras, 2011.

[19] Priyanto, Duwi. Mandiri Belajar SPSS, Jakarta: Buku Kita, 2008.

[20] Martono, Nanang. Metode Penelitian Kuantitatif, Jakarta: PT. Raja Grafindo, 2014, pp. 103.

[21] Siregar, Syofian. Statistik Parametrik untuk Penelitian Kuantitatif, Jakarta: Bumi Aksara, 2013, pp. 153.

[22] Priyanto, Duwi. SPSS 22: Pengolah Data Terpraktis. Yogyakarta: Andi, 2014, pp. 134.

[23] Sujianto, Agus Eko. Aplikasi Statistik dengan SPSS 16.0, Jakarta: Prestasi Pustaka, 2009 , pp. 97. 
